\title{
Is China a single united market for foreign investors? - Federalism, Chinese style and inward FDI in China
}

\author{
Eunsuk Hong \\ School of Finance and Management, \\ SOAS University of London, \\ Thornhaugh Street, Russell Square, \\ London WC1H 0XG, UK \\ Email: eh19@soas.ac.uk
}

\begin{abstract}
Whilst existing research on the locational determinants of inward foreign direct investment (FDI) in China and federalism, Chinese style makes important contributions to the literature in its own right, there has been a lack of formal econometric work in the literature to systematically quantify the relationship between location choice of foreign investors in China and federalism, Chinese style. This study develops a spatial dynamic model that explicitly addresses spatial externalities and path-dependent effects of inward FDI and host location attractiveness, in examining the spatial distribution of inward FDI in China under federalism, Chinese style. An empirical application of this model to a dataset of inward FDI across Chinese provinces over 1997 to 2012 shows that the location of FDI in China is determined by a combination of negative spatial externalities and positive path-dependent effects of FDI, and different host regional characteristics. This result implies that the Chinese market is highly fragmented for foreign investors.
\end{abstract}

Keywords: inward foreign direct investment; federalism, Chinese style; multinational enterprises; spatial dynamic panel model; China.

Reference to this paper should be made as follows: Hong, E. (2017) 'Is China a single united market for foreign investors? - Federalism, Chinese style and inward FDI in China', Int. J. Multinational Corporation Strategy, Vol. 2, No. 1, pp.76-94.

Biographical notes: Eunsuk Hong is a Senior Lecturer in International Business and Management (China) at SOAS University of London, UK. Before joining SOAS, he was a Lecturer in Strategy at Queen's University Belfast. He holds a $\mathrm{PhD}$ in Financial and Management Studies from the SOAS University of London. His current research focuses on the location strategies of multinational enterprises, and China specific institutional environment and its implications for the multinational enterprises doing business in China.

\section{Introduction}

The inflow of foreign direct investment (FDI) into China has played a vital role in both China's economic development and its integration into the global trade system. Starting from a base of less than USD 21 billion in 1990, the stock of FDI in China rose to over USD 1,221 billion by the end of 2015 (UNCTAD, 2016), which put China into the top 
two among all 165 developing economies, next to Hong Kong and third among the 21 Asia-Pacific Economic Cooperation (APEC) member economies ${ }^{1}$ only to the USA and Hong Kong. China has become the world's largest exporter of goods since 2009 and the world's number one trading nation by overtaking the USA since 2013, with a trade volume of over US\$4.3 trillion in 2014 (WTO, 2015). The rapid rise of China as a global trade power since the early 1990s has been, in large part, a direct result of FDI inflow on such a large scale. The share of exports by foreign-funded enterprises (FFEs) in China dramatically increased from only $1.1 \%$ in 1985 to $45.9 \%$ in 2014 (MOFCOM, 1992; NBS, 2015).

Due to the above facts, since the 1990s, China has been known as the 'world's factory'. Despite being the 'world's factory' at the national level, the regional distribution of inward FDI has been highly uneven across Chinese provinces. The consequence of such a trend makes China a highly-fragmented marketplace for foreign investors. By the end of 1997, the number of registered FFEs and the amount of their investment in the coastal region were 4.1 and 5.2 times larger than those in the inland region, respectively. ${ }^{2}$ Comparing the above indicators per province in the costal and the inland regions, the gap between these two regions has been wider. The coastal region is 7.1 and 9 times larger than the inland region in terms of the number of registered FFEs and the amount of their investment per province respectively (calculated based on NBS, 1999). With the aim of narrowing the regional economic gap between China's coastal and inland regions, China implemented the 'Great Western Development' strategy in 1999 and the 'Northeast China Revitalization' plan in 2003, and one of the major efforts has been to attract foreign investors in China's inland regions that had not enjoyed the economic benefits of China's initial open door policy. However, after a decade of the strategy, the gap of inward FDI activities between the two regions remains large. By the end of 2012, the number of registered FFEs and the amount of their investment in the coastal region were 4.4 and 4.8 times larger than those in the inland region respectively. Using these indicators per province, the coastal region is 7.6 and 8.2 times larger than the inland region in terms of the number of registered FFEs and the amount of their investments respectively (calculated based on NBS, 2014).

Given the prominent contribution of FDI to China's emergence as a global trade power and spatially uneven distribution of inward FDI, much scholarly work has been undertaken on the topic of location choice of foreign investors in China (e.g., Head and Rise, 1996; Wei et al., 1999; Cheng and Kwan, 2000; Coughlin and Segev, 2000; Zhang, 2001; Sun et al., 2002; Fung et al., 2002, 2005; He, 2006; Zheng, 2011; Sharma et al., 2014; Liang, 2015, among others). There have been two most commonly mentioned driving forces affecting FDI location choice in China. The first driving force is a China specific policy on inward FDI. In parallel with other areas of policy, the evolution of China's FDI policy has been characterised as pragmatic and incremental in terms of permitted locations, entry mode and permitted industry. Through preferential tax treatment and other measures, China's FDI policy has encouraged foreign investors to invest in selected industries, to use the desired entry mode, and to move into permitted locations (Tian, 2007). By doing so, FDI locations initially selected served as a test platform for China's economic reform (Naughton, 2007). The second driving force is the heterogeneity of regional factors across Chinese provinces. Variations in regional factors such as market size, income level, infrastructure, human capital, labour cost, and other endowments determine the attractiveness of a province as a destination for FDI. 
Empirical studies of this perspective argue that the reason FDI has mainly been in coastal provinces in China is due to their relatively strong locational advantages compared with inland provinces, the benefits of which can be reaped by foreign invested firms (Head and Rise, 1996; Zheng, 2011; Liang, 2015).

However, these two driving forces discussed above do not fully explain the spatial distribution of inward FDI in China. A remaining puzzle is the consistently widening gap of inward FDI between Chinese provinces, despite China's effort to narrow regional economic inequality by attracting foreign investments in the inland region. This study argues that China's specific institutional environment should be taken into account. Local protectionism and inter-regional competition for attracting foreign investments under Federalism, Chinese style, have played an important role in shaping a consistent trend of uneven spatial distribution of inward FDI across Chinese regions. Local protectionism and inter-regional competition among Chinese local governments has been a topical issue in China for years and has attracted much attention in both academic and policy arenas (Young, 2000; Wedeman, 2003; Bai et al., 2004, 2008; Poncet, 2005; Fang et al., 2013). Whilst existing research on the locational determinants of FDI in China and Federalism, Chinese style makes important contributions to the literature in its own right, there is a lack of research on the relationship between these two. In particular, there has been a lack of formal econometric work in the literature to quantify the relationship between Federalism, Chinese style and location choice of foreign investors in China. The only exception is He (2006) to my knowledge, which quantitatively examines how the process of regional decentralisation relates to FDI flows in the Chinese provinces. However, the author measures various types of decentralisation as static outcomes within a province rather than a dynamic process of inter-regional competition for attracting foreign investors. As such, proxies for decentralisations used in He (2006) can be interpreted as other indicators.

Considering the substantial importance of China as one of the world's top destinations for foreign investors, a better understanding of the FDI location choice of multinational enterprises (MNEs) in relation to the China-specific institutional environment would provide guidance to Chinese policy makers in identifying FDI policy priorities, and would also help MNEs in the formation and modification of their FDI location choice strategies in China.

This study aims to fill this important niche. The primary purpose of this study is to examine the mechanisms and driving forces determining MNEs' FDI location choices in China. It pays special attention to MNEs' responses to one of China's specific institutional environments - Federalism, Chinese style. To assess the impact of Federalism, Chinese style on FDI location choice of foreign investors in China, this study draws insights from a broad range of theoretical literature and develops an underlying model that explicitly addresses spatial externalities and path-dependent effects of inward FDI and location attractiveness under Federalism, Chinese style. Two hypotheses are constructed. The first hypothesis suggests that local protectionism and inter-regional competition for attracting FDI will lead to a negative spatial externality of inward FDI. The second hypothesis suggests that the nature of the Chinese Government's policies towards foreign investment - seeking incremental and marginal progress in terms of entry modes, location entry and industry entry - will lead to a positive path dependent effect of inward FDI. The dataset for the testing consists of a panel of 30 provinces and municipalities within the period of 1997 to 2012. The estimator this study employs is the system generalised method of moments (GMM) estimator. The system GMM is capable 
of correcting for the potential endogeneity of temporally and spatially lagged inward FDI variables and other explanatory variables, and allows for unobserved region-specific effects and measurement errors. The estimating results support both hypotheses by showing a negative spatial externality and a self-reinforcement tendency of inward FDI with respect to FDI location in China. Along with different location characteristics across Chinese provinces, these results explain why the spatial distribution of inward FDI in China has still been uneven despite a decade of efforts to attract FDI in the inland region of China.

The rest of this paper is organised as follows. Section 2 outlines Federalism, Chinese style and its implications for inward FDI in China, and develops the underlying model by incorporating temporal and spatial dynamics of MNEs' FDI location choice in China. Section 3 defines the key variables and describes the techniques used to estimate - the system GMM estimator. Section 4 estimates the models using the system GMM estimator and Section 5 reports the empirical results. Finally, Section 6 discusses the academic and policy implications of the findings and presents concluding remarks.

\section{Federalism, Chinese style - the institutional driving force of regional competition for FDI}

One of the most prominent institutional features of China's reform in promoting transition towards a market economy is a decentralised, multi-layered, multi-regional governance structure with a hard budget constraint, which is often described as 'Federalism, Chinese style' (Weingast et al., 1995; Cao et al., 1999). As a regulator of the local economy, local governments issued business licenses, coordinated local business developments, determined the structure of local expenditure, and engaged in tax policies (Qian, 1999; Zhao and Zhang, 1999; Wei, 2000; He, 2006). There are two implications of Chinese federalism for inward FDI in China. The first implication is the interregional competition for FDI. Given the immobility of domestic capital and financial market inefficiency in China, foreign capital is an important source for tax revenue generation and financing local development, implying that local officials are in competition to attract FDI and would like to offer competing packages of preferential policies (Naughton, 2007). As local governments increased their regulatory powers during the reform, they have strong incentives to attract foreign investors through lowering taxes, even beyond the statutory concessions specified in national level regulation, as long as FIEs increase tax revenue and boost employment (OECD, 2003). The second implication is local protectionism. Inter-regional competition provides local governments with incentives to take the form of using regional barriers on interregional trade and domestic capital flows to protect local businesses, profitable industries, and economic interests, such as sustaining employment and maximising tax revenues and non-tax benefits (Cannon and Zhang, 1996; Lee, 1998; Wedeman, 2003; Bai el al., 2004; He et al., 2008). For this reason, the Chinese market has been described as a collection of fragmented markets, reflecting the fact that China's factor and product markets are poorly integrated across different political jurisdictions of the country (Walder, 1995; Lee, 1998; Young, 2000; Huang, 2003). Given the high barriers on interregional trade and capital flows, and the central government's efforts to impose hard budget constraints on local governments, FDI provides a substitute mechanism for China's inefficient financial system of 
allocating investment funds. Moreover, the option for local governments to improve product quality is to attract foreign firms with their advanced managerial knowledge and technology (Huang, 2003).

\section{Hypothesis development}

\subsection{Underlying model}

The underlying model of this study is a spatial dynamic model that integrates three important elements in explaining the spatial distribution of inward FDI in China:

1 spatial externalities of FDI

2 path-dependency of FDI

3 host regional characteristics.

Following stock adjustment of Chow (1967) and Cheng and Kwan (2000), this study assumes that the stock of investment, $k$ adjusts partially toward its desired level with the following discrete process, using lower case letters for the natural logs of variables:

$$
k_{i t}-k_{i, t-1}=\lambda\left(k_{i t}^{*}-k_{i, t-1}\right), \quad 0<|\lambda|<1 .
$$

The equilibrium or desired FDI stock in province $i$ is also dependent on the desired stock in the neighbouring provinces:

$$
k_{i t}^{*}=\alpha k_{i, t-1}+\rho \cdot W k_{i t}^{*}+X_{i t} \pi+\delta_{i}+\theta_{i}+\varepsilon_{i t} .
$$

where $W$ refers to a $(N \times N)$ spatial weight matrix describing the spatial arrangement of the $N$ regions concerned and $w_{j k}$ the $(j, k)^{\text {th }}$ element of $W$, where $j$ and $k=1, \cdots, N$. The off-diagonal elements of $W$ are first defined as $w_{j k}=1 / d_{j k}$ where $d_{j k}$ is the distance between the capital city of province $j$ and that of province $k$, with $k \neq j$. This $W$ is then row-normalised so that each row sums to unity. $W k_{i t}$ can be interpreted as a proximity-weighted average of inward FDI stock into neighbouring provinces. $k_{i, t-1}$ represents path-dependent effect of inward FDI stock. $X_{i t}$ refers to the vector of host location variables, capturing standard regional variables for the host provinces. Combining equations (1) and (2) we obtain:

$$
k_{i t}-k_{i, t-1}=(I-\rho W)^{-1} \cdot \lambda \cdot\left(\alpha k_{i, t-1}+X_{i t} \pi+\delta_{t}+\theta_{i}+\varepsilon_{i t}\right)-\lambda k_{i, t-1},
$$

which can be rewritten as:

$$
(I-\rho W) k_{i t}=\lambda \cdot\left(\alpha k_{i, t-1}+X_{i t} \pi+\delta_{i t}+\theta_{i}+\varepsilon_{i t}\right)+(1-\lambda) \cdot(I-\rho W) k_{i, t-1} .
$$

This leads to:

$$
k_{i t}=\beta_{1} k l i, t-1+\beta_{2} W k_{i t}+\beta_{3} W k_{i, t-1}+X_{i t} \tilde{\pi}+\tilde{\delta}_{t}+\tilde{\theta}_{t}+\tilde{\varepsilon}_{i t},
$$

in which

$$
\beta_{1}=1-\lambda+\lambda \alpha, \beta_{2}=\rho, \beta_{3}=-(1-\lambda) \rho .
$$




\subsection{Spatial externalities}

$W k_{i t}$ in equation (2) implies a spatial dependence of MNEs' FDI locations, where the amount of inward FDI stock in one location partially depends upon inward FDI stock in neighbouring locations. Agglomerative forces of FDI in terms of specialised labour, infrastructure, and knowledge spillover may create positive spatial externalities, leading to higher FDI levels (Blonigen et al., 2007; Hall and Petroulas, 2008). However, in the context of China, the implication of inter-jurisdictional competition for the pattern of inward FDI location choices may differ from the conventional view of positive agglomeration effects, and rather it leads to negative spatial externalities. A body of empirical studies has indicated evidence of the existence and importance of local protectionism and inter-regional trade barriers in China (Young, 2000; Poncet, 2005; He et al., 2008). Young (2000) finds increasing similarity in the structure of economic activities across Chinese provinces, implying a rise of local protectionism. Using the inter-provincial trade flow of 21 comparable industries based on the provincial input-output tables of 1992 and 1997, Poncet (2005) supports the idea of a growing economic fragmentation in China by showing a decrease of inter-provincial trade intensity in addition to an increase of intra-provincial trade intensity between 1992 and 1997. The tariff-equivalent of crossing a border between a province and the rest of the country amounts to $48 \%$ and $53 \%$ in 1992 and 1997, respectively, being significantly higher than the value of $15 \%$ found for internal trade in the USA and Canada. Using industrial-provincial data between 1980 to 2003, He et al. (2008) examine the relationship between decentralisation driven protectionism and industrial distribution. Their empirical findings support the argument that local protectionism has hindered industrial specialisation. Although Coughlin and Segev (2000) and Sharma et al. (2014) apply spatial econometric models to analyse FDI location choice in China, the choice of empirical model is not based on a theoretical model that systematically combines the relationship between Federalism, Chinese style and China specific inward FDI policies, to account for an uneven distribution of FDI across Chinese provinces.

As described in Section 2, if inter-regional trade barriers and inter-regional competitions for inward FDI among provinces are so high that agglomeration effects cannot spill over, FDI in one province may be negatively influenced by FDI in neighbouring provinces, resulting in a win-lose game among provinces for receiving FDI. These explanations lead to the following hypothesis.

H1 Under Federalism, Chinese style, the FDI stock in a focal region will be negatively related to the FDI stock in its neighbouring regions.

\subsection{Path dependency}

$k_{i, t-1}$ in equation (1) captures a path dependent effect of FDI. In line with aspects of the new economic geography, the FDI location choice is not a single static decision function, but a dynamic one, indicating that current FDI location choice is partly a response to those in previous periods (Head et al., 1995; Barry et al., 2003). Since foreign firms face greater uncertainties than domestic firms in the host country, they typically have a strong tendency to follow previous investors because these investors can be represented as a signal of reliability of a certain FDI destination (Barry et al., 2003). Such a path dependent process of FDI has been tested (Head and Ries, 1996; Cheng and Kwan, 2000; 
Zheng, 2011) and they provide empirical evidence for a positive self-reinforcing effect of inward FDI. In line with the theory of incremental internationalisation, the previous FDI experiences provide options or platforms for sequential FDIs into a given location and give a chance to accumulate an experiential knowledge of foreign markets, which increases the level of resource commitments to overseas investments (Johanson and Vahlne, 1977; Davidson, 1980; Kogut, 1983; Chang, 1995; Shaver et al., 1997; Delios and Henisz, 2003). In the context of China, the consistently uneven spatial distribution of inward FDI stems from the China specific FDI policy, which further strengthens the path dependency of MNEs' FDI location choices in China. Through a strategy of 'experimental' reform, FDI was attracted and confined to the coastal region as an initial laboratory from the beginning of China's open door policy in 1979, and this discrimination against inland western regions has lasted for at least a decade, despite a gradual liberalisation of the regulation of inward FDI in terms of the location entry (OECD, 2002). A key policy injection in this laboratory was the establishment of various special zones with lower tax rates, fewer and simplified administrative and customs procedures, and duty-free import of components and supplies. In 1979, the first set of 'special economic zones (SEZs)' in Guangdong province (Shenzhen, Zhuhai and Shantou) and in Fujian (Xiamen) was established. Then, along the coastline, 14 new 'open cities' were opened in 1984 and all setup economic and technological development zones (ETDZs). In 1985, broad scopes of regions were opened to FDI, including the Pearl River Delta in Guangdong, the Yangtze River Delta around Shanghai and Min River Delta in south Fujian. Furthermore, Shandong and Liaoning peninsulas and the Bohai Sea Coastal Region were opened to foreign investment and Hainan Island became China's fifth SEZ in 1988. At the beginning of the 1990s, another SEZ - Pudong Development Zone - in Shanghai was established and 18 new ETDZs were approved in 1992 to 1993. During the same period, the regional scope of special zones started expanding to cities in the north and inland. Between 1992 and 1993, China opened 13 border cities, all the capital cities of inland provinces and ten interior cities along the Yangtze River. These cities were given the same preferential policy as the coastal open cities. Since 2000, China has strengthened the 'Great Western Development' strategy to expand the success of the 'special zones' policy in the coastal region to the inland region (Naughton, 2007). Such a variation in the government's preferential FDI policies among regions in China is one of the main driving forces of the uneven regional distribution of FDI, which further widens regional income and economic development inequalities in China (Wei et al., 1999; He, 2006; Zheng, 2011).

If we assume the selective and incremental approach of China's FDI policies and a win-lose game among provinces for attracting inward FDI under Federalism, Chinese style, regions which attracted FDI in the first round will attract more FDI (e.g., coastal regions), whilst regions which attracted low inward FDI in the initial round will have decreased chances of attracting FDI as time unfolds, indicating a path dependent effect of inward FDI in China. This leads us to the following hypothesis.

H2 Under Federalism, Chinese style and the selective approach of China's policies towards FDI, the current FDI stock in a focal region will be positively related to the previous FDI stock in the same region. 


\section{Empirical model specification and estimation method}

\subsection{Empirical model specification}

Empirical model specification of equation (4) is a spatial dynamic panel model as follows:

$$
\begin{aligned}
\ln \left(F D I_{\text {Stock }}\right)_{i t} & =\beta_{1} \ln \left(F D I_{\text {Stock }}\right)_{i, t-1}+\beta_{2}\left(W \cdot F D I_{\text {Stock }}\right)_{i t}+\beta_{3} \ln \left(W \cdot F D I_{\text {Stock }}\right)_{i, t-1} \\
& +\beta_{4} \text { HostLocation Variables } i t+\delta_{t}+\theta_{i}+\varepsilon_{i t} .
\end{aligned}
$$

To measure inward FDI stock in China, which is the dependent variable in the model, this study uses the logarithm of the accumulated investment of foreign funded enterprises in region $i$ and year $t\left[\ln \left(F D I_{\text {Stock }}\right)_{i t}\right]$. Data used in estimations is a panel of 30 provinces and municipalities over the period 1998 to 2012. Among all 31 provinces and municipalities in China, Tibet is excluded mainly because of data unavailability. There are three independent variables. First, $\ln \left(F D I_{\text {Stock }}\right)_{i, t-1}$ refers to the path dependent effect of inward FDI stock. Second, $\ln \left(W \cdot F D I_{\text {Stock }}\right)_{\text {it }}$ refers to spatial externalities of inward FDI stock. Third, $\ln \left(W \cdot F D I_{\text {Stock }}\right)_{i, t-1}$ refers to the path dependent effect of FDI spatial externalities. The vector 'host location variables' captures the standard regional determinants of inward FDI, which will be specified in the next section; and the disturbance terms consist of the unobserved time effect that is common for all regions $\left(\delta_{t}\right)$; the unobserved regional fixed effect that is constant over time $\left(\theta_{i}\right)$, and the transitory errors $\left(\varepsilon_{i t}\right)$ that may vary across regions and over time with a zero mean value. The data for inward FDI stock is obtained from the China Statistical Yearbook (various years) published by the National Bureau of Statistics in China.

\subsection{Host location variables}

'Host location variables' represent the key host regional characteristics. The literature of MNEs' location decision on international business, economic geography, and international economics suggests that the spatially uneven distribution of FDI activities across countries or regions in a given country derives from the presence of substantially different regional characteristics such as market size, income level, infrastructure, human capital, labour cost, and other endowments (Dunning, 1977; Markusen et al., 1996; Mucchieli and Mayer, 2004; Iammarino and McCann, 2013) and these regional factors are often heterogeneous and immobile across regions (Arthur, 1994; Krugman, 1991; Fujita and Thisse, 2002). In line with the literature on the regional determinants of MNEs' FDI location choice in China, this study incorporates four aspects of such host regional characteristics in empirical estimation. First, the host region market size is measured by the logarithm of gross regional product in the region $i$ and year $t$ and denoted as $\ln G R P_{i t}$. This study expects that the larger the market size of a host province is, other things being equal, the more inward FDI the province attracts because it provides investment opportunities for foreign investors who look for new markets or seek to maximise the expected revenue of their investment (Cheng and Kwan, 2000; Zhang, 2001; Sun et al., 2002; Fung et al., 2002, 2005; Zheng, 2011; Sharma et al., 2014; Liang, 2015). Second, regional innovative capabilities are measured by the logarithm of the number of patent applications in the region $i$ and year $t$ and denoted as $\ln P A T E N T_{i t}$. The patents registered are considered as the output of regional knowledge production (Buesa 
et al., 2010) and they are closely related with other input resources such as R\&D expenses and human capital (Acs et al., 2002). This study expects that the higher level of regional innovative capabilities, the more inward FDI the province attracts because a region with higher innovative capabilities can provide more efficient and innovative ways to boost productivity for foreign investors. Third, this study uses two infrastructure variables measured by the logarithm of total length of railways and highways per 1,000 square kilometres of landmass in the region $i$ and year $t$ and denoted as $\ln R A I L_{i t}$ and $\ln R O A D_{i}$, respectively. The existing literature on determinants of inward FDI in China finds that well-developed infrastructure with convenient transportation options can improve the effectiveness of MNE operations in the host region and reduce transport costs (Cheng and Kwan, 2000; Zhang, 2001; Sun et al., 2002; Fung et al., 2002, 2005; Zheng, 2011). This study expects that a denser transportation network will lead to larger FDI inflow. Fourth, the quality of human capital is measured by a ratio of the number of students enrolled in higher educational institutions in the province $i$ and year $t$ to its population during the same period and denoted as $\ln E D U_{i t}$. Access to skilled labour in the host region is one of the key considerations for FDI location because FDI by MNEs typically leads to the advancement and innovations in production, management, and marketing activities in the host regions. A higher education level generally reflects the capability of employees to process and understand information and to cope with the new tasks and procedures required by foreign investors (OECD, 2002). Following existing empirical literature (Fung et al., 2002; Carstensen and Toubal, 2004; Liang, 2015), this study predicts a positive relationship between the quality of human capital and inward FDI. The data for the above variables is obtained from the China Statistical Yearbook (various years).

\subsection{Estimation method}

This study uses a spatial dynamic panel regression with system GMM to address the endogeneity issue of serially and spatially lagged dependent variables. As pointed out by Hsiao (2003), the pooling OLS estimation of the coefficient $\left(\beta_{1}\right)$ on a serially lagged dependent variable $\left[\ln \left(F D I_{\text {Stock }}\right)_{i, t-1}\right]$ is likely to produce inconsistent and upward-biased results, owing to the positive correlation between a time lagged dependent variable $\left[\ln \left(F D I_{\text {Stock }}\right)_{i, t-1}\right]$ and fixed effects $\left(\theta_{i}\right)$. The inclusion of a spatially lagged dependent variable $\left[\ln \left(W \cdot F D I_{\text {Stock }}\right)_{i t}\right]$ on the right-hand side of the model further causes simultaneity and endogeneity problems, which would make OLS estimators biased and inconsistent (Anselin, 1988). Therefore, both the serially and spatially lagged dependent variables need to be treated as endogenous, and the proper estimation of their coefficients ( $\beta_{1}$ and $\beta_{2}$ ) should account for this endogeneity issue in an explicit manner.

In addition to the endogeneity issue of serially and spatially lagged dependent variables, there is another potential endogeneity problem between inward FDI stock levels and one of our regional variables, regional innovative capabilities, $\ln P A T E N T_{i t}$. Some geographic regions may be attractive and conducive to both FDI and patent activities simultaneously. Furthermore, large inward FDI stock in a given region may attract innovative activities (e.g., R\&D laboratories) to the region. As such, a lack of control of potential endogeneity issues may generate biased and inconsistent empirical results. One possible way to address the potential endogeneity problem is to identify suitable instrumental variables (IVs) that are highly correlated with the endogenous 
variables, but not correlated with the error term, and then run IV regressions. In most cases, however, it is not easy to find the instruments equipped with such ideal properties. The difference GMM method can deal with this joint endogeneity issue by using the level of the lagged terms of endogenous variables as IVs after first differencing, because these lagged variables are very unlikely to be correlated with the error term after the first-difference (Arellano and Bond, 1991). However, Blundell and Bond (1998) shows that if the series are persistent, difference GMM performs poorly because past levels convey little information about future changes and thus are difficult to instrument. The system GMM method suggested in Blundell and Bond (1998) handles this weak instrument problem by adding moment conditions and combining 'the original level equation' and 'the difference equation' as a system of equations, with first-differences instrumented on lagged levels and with levels instrumented on first differences. By doing so, the system GMM makes instruments exogenous to the fixed effects and increases efficiency. Monte Carlo investigations in Kukenova and Monteiro (2008) suggest that an application of the system GMM to spatial dynamic panel models [e.g., equation (5)] deals with the joint endogeneity problem of serial and spatial dependences and corrects for the potential endogeneity of other explanatory variables.

To guarantee that the selected set of lagged level and first-differenced values of the explanatory variables are valid and relevant instruments in the regression, this paper conducts and reports three validity tests:

1 Hansen's J test of over-identifying restrictions to test for the overall validity of the IVs.

2 Difference-in-Hansen tests with the number of instruments reported (Roodman, 2009).

3 First-order $\mathrm{AR}(1)$ and second-order $\mathrm{AR}(2)$ serial correlation tests in the first-differenced residuals.

If the original error terms are not serially correlated, AR(1) should be significant and $A R(2)$ should be insignificant. In addition to the validity tests, a finite-sample correction for the two-step covariance matrix proposed by Windmeijer (2005) is applied.

\section{Empirical results}

Table 1 presents the descriptive statistics and a correlation matrix of the variable and Table 2 reports the results of equation (5) using the system GMM estimator. Due to the high correlation between $\ln \left(W \cdot F D I_{\text {Stock }}\right)_{i t}$ and $\ln \left(W \cdot F D I_{\text {Stock }}\right)_{i, t-1}(r=0.99)$, they are included in a separate regression model specification in Table 2 [models 1 to 4 are based on using $\ln \left(W \cdot F D I_{\text {Stock }}\right)_{i t}$ and models 5 to 8 are based on using $\left.\ln \left(W \cdot F D I_{\text {Stock }}\right)_{i, t-1}\right]$. Among control variables, because correlations between $\ln G R P_{i t}$ and $\ln P A T E N T_{i t}$, and between $\ln R A I L_{i t}$ and $\ln R O A D_{i t}$ are high ( $r=0.94$ and 0.76 , respectively), they are also included in a separate model specification in Table 2 [models 1 to 2 and 5 to 6 are based on using $\ln G R P_{i t}$, and models 3 to 4 and 7 to 8 are based on using $\ln P A T E N T_{i t}$; models 1 , 3,5 and 7 are based on using $\ln R A I L_{i t}$ and models 2, 4, 6 and 8 are based on using $\left.\ln R O A D_{i t}\right]$. The last four rows in Table 2 show that the system GMM estimation 
passes all the specification tests of Hansen's J, difference-in-Hansen, the first-order and second-order serial correlation tests, indicating that the IVs selected in the regression are statistically valid and the original error terms are not serially correlated.

Several important findings can be spelled out. First, the coefficients on five host locational variables are all statistically significant and have the expected signs except human capital variable $\left(\ln E D U_{i t}\right)$ in models 3, 4, 7 and 8 in Table 2, in which coefficients of $\ln E D U_{i t}$ are statistically insignificant. This empirical evidence thus suggests that provinces that are characterised by a larger host market size $\left(\ln G R P_{i t}\right)$, a higher level of innovation capabilities $\left(\ln P A T E N T_{i t}\right)$, a more developed transportation infrastructure $\left(\ln R A I L_{i t}\right.$ and $\left.\ln R O A D_{i t}\right)$, and more educated human capital $\left(\ln E D U_{i t}\right)$ lead to a higher level of inward FDI. In detail, the coefficient of host market size variable $\left(\ln G R P_{i t}\right)$ across models are between 0.235 (model 2) and 0.452 (model 1), indicating that a $1 \%$ increase of market size in a host province is likely to increase the amount of inward FDI stock in the same province by $0.235 \%$ to $0.452 \%$, and they are all statistically significant at $1 \%$ level. The coefficient value of innovation capabilities $\left(\ln P A T E N T_{i t}\right)$ ranges between 0.108 (model 8) and 0.214 (model 3), indicating that a $1 \%$ increase of the number of patent applications in a host province is likely to increase the amount of inward FDI stock in the same region by $0.108 \%$ to $0.214 \%$, and they are all statistically significant at $1 \%$ level. The overall effect of road transport density on inward FDI stock is larger than that of rail transport density. The coefficient of the density of rail transport network $\left(\ln R A I L_{i t}\right)$ ranges 0.108 (model 3) and 0.123 (model 5), indicating that a $1 \%$ increase of density of rail transport network in a province is likely to increase the amount of inward FDI stock in the same region by $0.108 \%$ to $0.213 \%$, and they are all statistically significant at $5 \%$ level. Meanwhile, the coefficient of the density of the road transport network $\left(\ln R O A D_{i t}\right)$ on inward FDI stock ranges between 0.150 (model 8) and 0.216 (model 2), indicating that a $1 \%$ increase of road transport network density in a host province is likely to increase the amount of inward FDI stock in the same region by $0.150 \%$ to $0.216 \%$, and they are all statistically significant at either $1 \%$ level or $5 \%$ level. The coefficient of human capital variable $\left(\ln E D U_{i t}\right)$ in models $1,2,5$, and 6 is statistically significant at $5 \%$ and the size of the coefficient ranges between 0.165 (model 2) and 0.224 (model 5), indicating that a $1 \%$ increase of the ratio of students enrolled in higher educational institutions over the total population in a host province is likely to increase the amount of inward FDI stock in the same region by $0.165 \%$ to $0.224 \%$.

Secondly, it shows a win-lose game among Chinese provinces in attracting FDI through local protectionism. Consistent with Sharma et al. (2014), the coefficient of $\ln \left(W \cdot F D I_{\text {Stock }}\right)_{i t}$ and $\ln \left(\mathrm{W} \cdot F D I_{\text {Stock }}\right)_{i, t-1}$ are significantly negative for all eight model specifications, indicating that competition for attracting FDI among provinces is so high that it wipes out the spillover effects of agglomeration from FDI, and the interregional competition makes China a highly-fragmented market for foreign investors. In detail, the coefficient size of $\ln \left(W \cdot F D I_{\text {Stock }}\right)_{i t}$ and $\ln \left(\mathrm{W} \cdot F D I_{\text {Stock }}\right)_{i, t-1}$ range between -0.932 (model 9) and -0.518 (model 4), indicating that a $1 \%$ increase of both current and previous inward FDI stock in the neighbouring provinces is likely to decrease the amount of current inward FDI stock in the focal province by $0.932 \%$ to $0.518 \%$, and they are all statistically significant either at $1 \%$ or $5 \%$ level. All these estimations provide strong and robust support to Hypothesis 1. 
Is China a single united market for foreign investors?

Table 1 Descriptive statistics and correlation matrix ${ }^{\mathrm{a}, \mathrm{b}}$

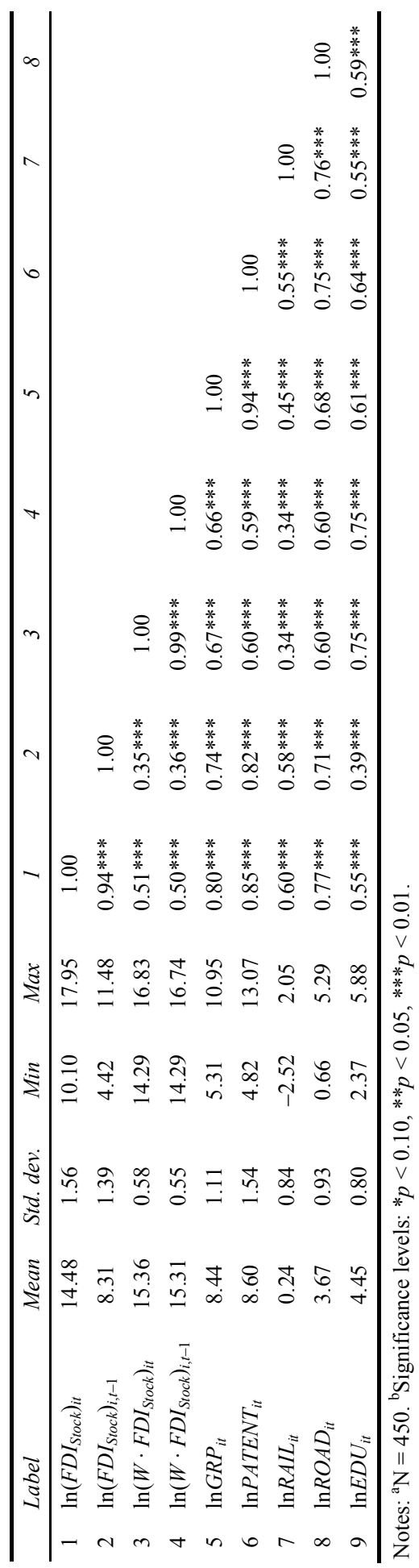


Table 2 Temporal and spatial adjustment and location determinants of inward FDI in China based on equation (6)

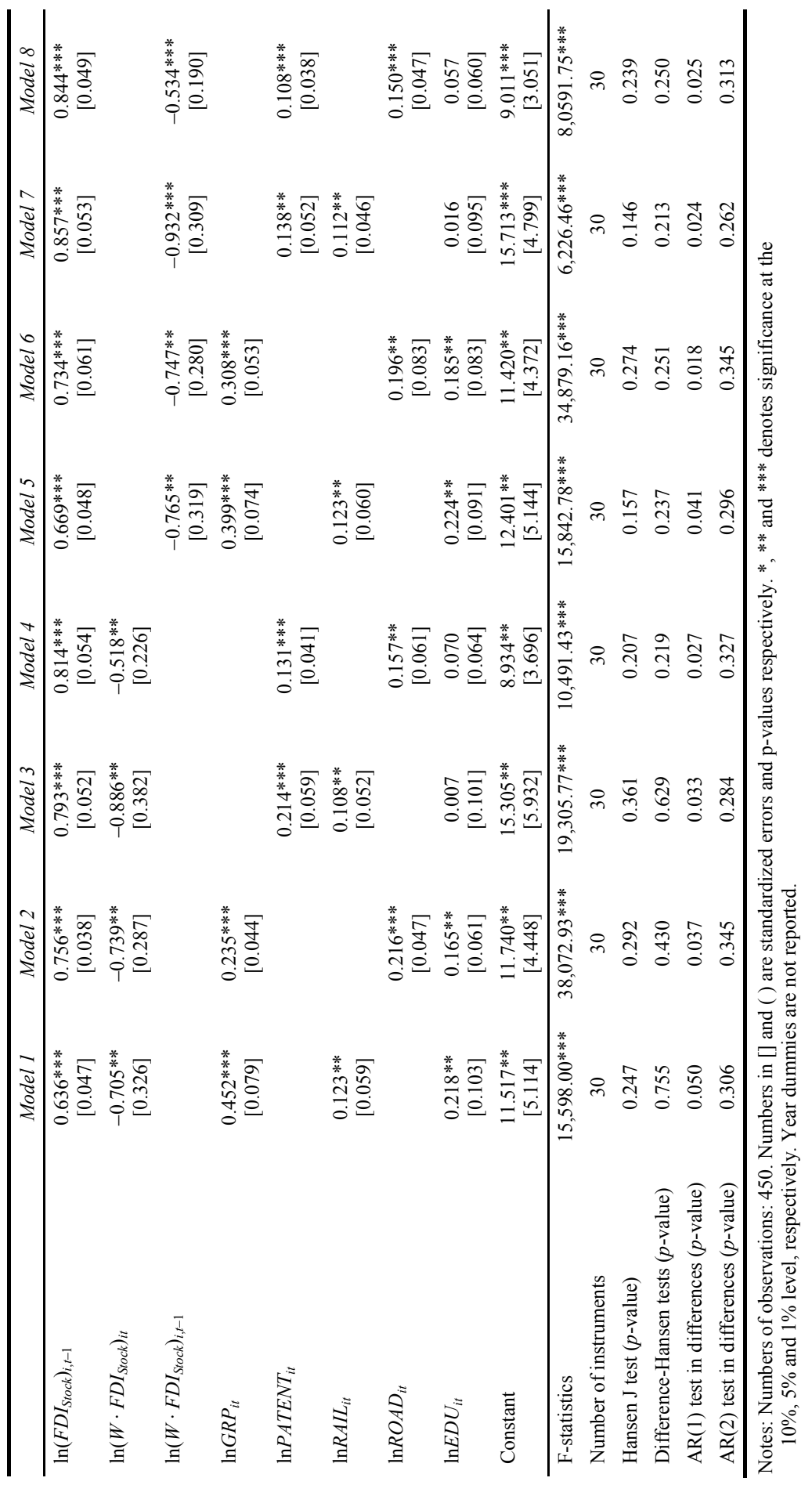


Thirdly, it shows that the FDI location choice in China is highly dependent upon previous investment location choices of foreign investors. As suggested by Head and Ries (1996), Cheng and Kwan (2000) and Zheng (2011), the coefficient of $\ln \left(F D I_{\text {Stock }}\right)_{i, t-1}$ is positive and statistically significant across all model specifications, indicating strong selfreinforcement effects of MNEs' FDI location choices in China. The range of coefficient for previous inward FDI stock $\ln \left(F D I_{\text {Stock }}\right)_{i, t-1}$ is between 0.636 (model 1) and 0.857 (model 7), indicating that a $1 \%$ increase of previous inward FDI stock in a host province is likely to increase the amount of current inward FDI stock in the same region by $0.636 \%$ to $0.857 \%$, and they are all statistically significant at $1 \%$ level. All these results support Hypothesis 2.

Together with a negative spatial externality of FDI created by Federalism, Chinese style, and a positive path-dependent effect of FDI which derives not only from geographical advantages enjoyed by the coastal regions in terms of transportation infrastructure and availability of skilled human capital, but also an incremental evolution of China's FDI policy in terms of permitted location, this study provides a clue to the consistently high degree of spatially uneven distribution of inward FDI in China despite China's effort to boost the poorer western inland parts of the country that have not enjoyed the economic benefits of China's opening up to the outside world. This conclusion is consistent with Zheng (2011), indicating that the prime causes of the uneven regional distribution of FDI are variations in economic openness (government's preferential policies) and industrial and economic development in terms of market size, human resources, agglomeration, and infrastructure, which further widens income and economic development inequalities among the three macro-regions.

\section{Concluding remarks}

Despite a substantial body of literature on the issue of locational determinants of inward FDI in China, there has been a lack of econometric research based on a theoretical model to quantitatively assess MNE's responses to the China-specific decentralised institutional environment when they determine FDI locations in China. This study has addressed this challenge and thus filled an important niche in the literature.

The underlying model is a spatial dynamic model that explicitly incorporates spatial externalities of inward FDI, path-dependent effects of inward FDI, and other major host regional characteristics. This study applies this spatial dynamic model to the dataset of inward FDI in Chinese provinces and municipalities over the period of 1997 to 2012. The estimations must address the joint endogeneity problem of the temporally and spatially lagged dependent variable, and thus this study employs the system GMM estimator to deal with this joint endogeneity problem and endogeneity issue of other explanatory variables.

Consistent with previous empirical literature on locational determinants of inward FDI in China, this study has found that foreign investors favour provinces characterised by large host market size, adequate transportation linkages, high level of innovation capabilities, and more educated human capital. However, empirical results of this study also reveal a negative impact of FDI spatial externalities while a positive impact of FDI path-dependency on the MNEs' FDI location choice in China, and this combined result 
may explain the reason for maintaining a persistent gap between the coastal and inland regions in China, in terms of regional distribution of inward FDI.

An interesting policy implication can be derived from this research. This study finds that the major reason for the consistently uneven distribution of inward FDI in China despite its effort to attract more FDI in the inland regions is a negative impact of inter-regional competition among Chinese provinces driven by Federalism, Chinese style. Under the China-specific decentralised governance structure, although policies and regulations toward FDI carefully formulated by the central government under the 'Great Western Development' strategy in 1999 and 'Northeast China Revitalization' plan in 2003 are reasonable at national level, implementation of these FDI policies varies widely across different local governments due to their different local interests and regional competition for foreign investments. Therefore, the formulation of the preferential FDI policy aiming to narrow a regional gap of inward FDI alone may not be a sufficient condition. A policy which narrows a wide gap between the formulation of FDI policies and its implementation should also be present. Furthermore, a series of complementary policies and regulations should be introduced together with the FDI policy, such as promoting both domestic and foreign investment in developing transportation infrastructure, strengthening regional education and training institutions, and attracting skilled labour to the inland region.

In addition to revealing the above insightful findings and their policy implications, this study also contributes to the international business literature by quantitatively modelling the effect of the China-specific decentralised institutional environment on the location choice of foreign investors in China. The empirical findings suggest that China is actually not a single united market, but the Chinese market is highly fragmented for foreign investors. In practice, such a fragmented Chinese market environment with the decentralised implementation of FDI policies may provide a high bargaining power for foreign investors relative to local governments because foreign investors can play Chinese local governments off against each other in search of a favourable FDI policy at local level. As argued by Naughton (2007), however, strong inter-regional competition for attracting FDI among Chinese local governments may force foreign investors to navigate highly uncooperative and complex relationships between different regional or sectoral authorities, and this navigation can be costly for foreign investors. This important implication encourages foreign investors to pay more attention to a systematic approach in assessing the benefits and costs of their FDI location choices in the Chinese institutional context.

This study is limited by the aggregate FDI data stock at the provincial level. Due to this limitation, this study is only able to test the spatial externalities of inward FDI stock for the aggregate bundle of products and industries. Considering the incremental nature and diverse features of China's industrial restructuring and FDI policies, further research should be directed at empirically distinguishing spatial externalities by product and industry levels across provinces when data at the further disaggregate level become available. However, the modelling framework of this research and the associated empirical testing methods are clearly applicable to similar data from other countries. Future research in this direction would be able to check the extent to which the findings of this research can be generalised. 


\section{References}

Acs, Z.J., Anselin, L. and Varga, A. (2002) 'Patents and innovation counts as measures of regional production of new knowledge', Research Policy, Vol. 31, No. 7, pp.1069-1085.

Anselin, L. (1988) Spatial Econometrics: Methods and Models, Kluwer Academic Publishers, Boston.

Arellano, M. and Bond, S. (1991) 'Some test of specification for panel data: Monte Carlo evidence and an application to employment equations', Review of Economic Studies, Vol. 58, No. 2, pp.277-297.

Arthur, W.B. (1994) Increasing Returns and Path Dependence in the Economy, University of Michigan Press, Ann Arbor.

Bai, C-E., Du, Y., Tao, Z. and Tong, S.Y. (2004) 'Local protectionism and regional specialization: evidence from China's industries', Journal of International Economics, Vol. 63, No. 2, pp.397-417.

Bai, C-E., Tao, Z. and Tong, S.Y. (2008) 'Bureaucratic integration and regional specialization in China', China Economic Review, Vol. 19, No. 2, pp.308-319.

Barry, F., Gorg, H. and Strobl, E. (2003) 'Foreign direct investment, agglomerations, and demonstration effects: an empirical investigation', Review of World Economics, Vol. 139, No. 4, pp.583-600.

Blonigen, B.A., Davies, R.B., Waddell, G.R. and Naughton, H.T. (2007) 'FDI in space: spatial autoregressive relationships in foreign direct investment', European Economic Review, Vol. 51, No. 5, pp.1303-1325.

Blundell, R.W. and Bond, S. (1998) 'Initial conditions and moment restrictions in dynamic panel data models', Journal of Econometrics, Vol. 87, No. 1, pp.115-143.

Buesa, M., Heijs, J. and Baumert, T. (2010) 'The determinants of regional innovation in Europe: a combined factorial and regression knowledge production function approach', Research Policy, Vol. 39, No. 6, pp.722-735.

Cannon, T. and Zhang, L. (1996) 'Inter-region tension and China's reform', in Cook, I.G., Doel, M.A. and Li, R. (Eds.): Fragmented Asia, pp.75-101, Ashgate, Aldershot.

Cao, Y., Qian, Y. and Weingast, B.R. (1999) 'From federalism, Chinese style to privatization, Chinese style', Economics of Transition, Vol. 7, No. 1, pp.103-131.

Carstensen, K. and Toubal, F. (2004) 'Foreign direct investment in Central and Eastern European countries: a dynamic panel analysis', Journal of Comparative Economics, Vol. 32, No. 1, pp.3-22.

Chang, S.J. (1995) 'International expansion strategy of Japanese firms: capability building through sequential entry', Academy of Management Journal, Vol. 38, No. 2, pp.383-407.

Cheng, L.K. and Kwan, Y.K. (2000) 'What are the determinants of the location of foreign direct investment? The Chinese experience', Journal of International Economics, Vol. 51, No. 2, pp.379-400.

Chow, G.C. (1967) 'Technological change and the demand for computers', American Economic Review, Vol. 57, No. 5, pp.1117-1130.

Coughlin, C.C. and Segev, E. (2000) 'Foreign direct investment in China: a spatial economic study', World Economy, Vol. 23, No. 1, pp.1-23.

Davidson, W. (1980) 'The location of foreign direct investment activity: country characteristics and experience effects', Journal of International Business Studies, Vol. 12, No. 2, pp.9-22.

Delios, A. and Henisz, W. (2003) 'Political hazards, experience, and sequential entry strategies: the international expansion of Japanese firms, 1980-1998', Strategic Management Journal, Vol. 24, No. 11, pp.1153-1164.

Dunning, J.H. (1977) 'Trade, location of economic activity and the MNE: a search for an eclectic approach', in Ohlin, B., Hesselborn, P.O. and Wijkman, P.M. (Eds.): The International Allocation of Economic Activity, pp.395-418, Macmilla, London n 
Fang, Y., Qi, L. and Lin, Z. (2013) 'China's internal borders: evidence from business-cycle correlations across Chinese cities', Chinese Economy, Vol. 46, No. 3, pp.41-60.

Fujita, M. and Thisse, J-F. (2002) Economics of Agglomeration: Cities, Industrial Location, and Regional Growth, Cambridge University Press, London and New York.

Fung, K.C., Garcia-Herrero, A., Iizaka, H. and Siu, A. (2005) 'Hard or soft? Institutional reforms and infrastructure spending as determinants of foreign direct investment in China', Japanese Economic Review, Vol. 56, No. 4, pp.408-416.

Fung, K.C., Iizaka, H. and Parker, S. (2002) 'Determinants of U.S. and Japanese direct investment in China', Journal of Comparative Economics, Vol. 30, No. 3, pp.567-578.

Hall, S. and Petroulas, P. (2008) Spatial Interdependencies of FDI Locations: A Lessening of the Tyranny of Distance?, Bank of Greece Working Paper, No. 67.

He, C. (2006) 'Regional decentralization and the location of foreign direct investment in China', Post-Communist Economies, Vol. 18, No. 1, pp.33-50.

He, C., Wei, Y.D. and Xie, X. (2008) 'Globalization, institutional change, and industrial location: economic transition and industrial concentration in China', Regional Studies, Vol. 42, No. 7, pp.923-945.

Head, K. and Ries, J. (1996) 'Inter-city competition for foreign investments: static and dynamic effects of China's incentive area', Journal of Urban Economics, Vol. 40, No. 1, pp.38-60.

Head, K., Ries, J. and Swenson, D. (1995) 'Agglomeration benefits and location choice: evidence from Japanese manufacturing investments in the United States', Journal of International Economics, Vol. 38, Nos. 3-4, pp.223-247.

Hsiao, C. (2003) Analysis of Panel Data, Cambridge University Press, New York.

Huang, Y. (2003) Selling China: Foreign Direct Investment During the Reform Era, Cambridge University Press, New York.

Iammarino, S. and McCann, P. (2013) Multinationals and Economic Geography: Location, Technology and Innovation, Edward Elgar, Cheltenham.

Johanson, J. and Vahlne, J-E. (1977) 'The internationalization process of the firm: a model of knowledge development and increasing foreign market commitment', Journal of International Business Studies, Vol. 8, No. 1, pp.23-32.

Kogut, B. (1983) 'Foreign direct investment as a sequential process', in Kindleberger, C. and Audretsch, D. (Eds.): The Multinational Corporation in the 1980s, pp.35-56, MIT Press, Cambridge.

Krugman, P. (1991) 'Increasing returns and economic geography', Journal of Political Economy, Vol. 99, No. 3, pp.483-499.

Kukenova, M. and Monteiro, J-A. (2008) Spatial Dynamic Panel Model and System GMM: A Monte Carlo Investigation, MPRA Paper No. 14319.

Lee, P.K. (1998) 'Local economic protectionism in China's economic reform', Development Policy Review, Vol. 16, No. 3, pp.281-303.

Liang, Y. (2015) 'The determinants and structural change of FDI in China - a study based on city-level panel data', Journal of Applied Business Research, Vol. 31, No. 4, pp.1519-1530.

Markusen, J.R., Venables, A.J., Konan, D.E. and Zhang, K.H. (1996) A Unified Treatment of Horizontal Direct Investment, Vertical Direct Investment, and the Pattern of Trade in Goods and Services, NBER, Working Paper No. 5696.

Ministry of Commerce (MOFCOM) (1992) Almanac of China's Foreign Economic Relations and Trade 1992, China Foreign Economic Relations and Trade Publishing House, Beijing.

Mucchieli, J.L. and Mayer, T. (2004) Multinational Firms' Location and the New Economic Geography, Edward Elgar, Cheltenham.

National Bureau of Statistics (NBS) (1999, 2014, 2015) China Statistical Yearbook, China Statistical Publishing House, Beijing.

Naughton, B. (2007) The Chinese Economy: Transitions and Growth, MIT Press, London. 
OECD (2002) 'Technology challenges for China's industries', China in the World Economy: The Domestic Policy Challenges, pp.193-230, Paris.

OECD (2003) OECD Investment Policy Reviews-China: Progress and Reform Challenges, Paris.

Poncet, S. (2005) 'A fragmented china: measure and determinants of Chinese domestic market disintegration', Review of International Economics, Vol. 13, No. 3, pp.409-430.

Qian, Y. (1999) The institutional Foundation of China's Market Transition, World Bank, Washington, DC.

Roodman, D. (2009) 'A note on the theme of too many instruments', Oxford Bulletin of Economics and Statistics, Vol. 71, No. 1, pp.135-158.

Sharma, S.D., Wang, M. and Wong, M.C.S. (2014) 'FDI location and the relevance of spatial linkages: evidence from provincial and industry FDI in China', Review of International Economics, Vol. 22, No. 1, pp.86-104.

Shaver, M.J., Mitchell, W. and Yeung, B. (1997) 'The effect of own-firm and other-firm experience on foreign direct investment survival in the United States, 1987-1992', Strategic Management Journal, Vol. 18, No. 10, pp.811-824.

Sun, Q., Tong, W. and Yu, Q. (2002) 'Determinants of foreign direct investment across China', Journal of International Money and Finance, Vol. 21, No. 1, pp.79-113.

Tian, X. (2007) Managing International Business in China, Cambridge University Press, New York.

UNCTAD (2016) Global Investment Trends Monitor, No. 22, 20 January.

Walder, A.G. (1995) 'Local governments as industrial firms: an organizational analysis of China's transitional economy', American Journal of Sociology, Vol. 101, No. 2, pp.263-301.

Wedeman, A.H. (2003) From Mao To Market: Rent Seeking, Local Protectionism, and Marketization in China, Cambridge University Press, New York.

Wei, Y., Liu, X., Parker, D. and Vaidya, K. (1999) 'The regional distribution of foreign direct investment in China', Regional Studies, Vol. 33, No. 9, pp.857-867.

Wei, Y.D. (2000) Regional Development in China: Status, Globalization, and Inequality, Routledge, London.

Weingast, B.R., Qian, Y. and Montinola, G. (1995) 'Federalism, Chinese style: the political basis for economic success in China', World Politics, Vol. 48, No. 1, pp.50-81.

Windmeijer, F. (2005) 'A finite sample correction for the variance of linear efficient two-step GMM estimators', Journal of Econometrics, Vol. 126, No. 1, pp.25-51.

World Trade Organization (WTO) (2015) International Trade Statistics 2015.

Young, A. (2000) 'The razor's edge: distortions and incremental reform in the People's Republic of China', Quarterly Journal of Economics, Vol. 115, No. 4, pp.1091-1135.

Zhang, K.H. (2001) 'What attracts foreign multinational corporations to China?', Contemporary Economic Policy, Vol. 19, No. 3, pp.336-346.

Zhao, X.B. and Zhang, L. (1999) 'Decentralization reforms and regionalism in China: a review', International Regional Science Review, Vol. 22, No. 3, pp.251-281.

Zheng, P. (2011) 'The determinants of disparities in inward FDI flows to the three macro-regions of China', Post-Communist Economies, Vol. 23, No. 2, pp.257-270. 


\section{Notes}

1 The APEC member economies are Australia, Brunei, Canada, Indonesia, Japan, South Korea, Malaysia, New Zealand, the Philippines, Singapore, Thailand, the USA, Taiwan, Hong Kong, China, Mexico, Papua New Guinea, Chile, Peru, Russia, and Vietnam.

2 Coastal region includes Guangdong, Jiangsu, Shandong, Shanghai, Fujian, Zhejiang, Liaoning, Beijing, Tianjin, Hebei, Hainan; Inland region includes Guangxi, Hubei, Hunan, Jiangxi, Henan, Anhui, Heilongjiang, Jilin, Shanxi, Inner Mongolia, Chongqing, Sichuan, Shaanxi, Yunnan, Gansu, Guizhou, Qinghai, Xinjiang, and Ningxia. 